\title{
Signs of a Totalitarian System in Architecture of Socialist Realism
}

\author{
WOLFOVÁ Marie ${ }^{1, a}$, ŠEVČíKOVÁ Hana ${ }^{2, b}$, RYKALOVÁ Eva ${ }^{3, c}$ \\ and FABIAN Radek ${ }^{4, d^{*}}$ \\ 1, 2, 3,4 Faculty of Civil Engineering, VSB - Technical University of Ostrava, L. Podéště 1875, 708 \\ 33 Ostrava-Poruba, Czech Republic

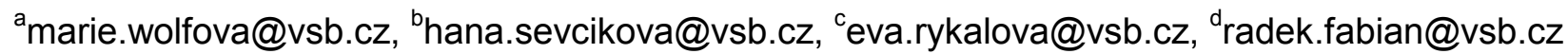

Keywords: Architecture, propagation, ideology, totalitarian system, socialist realism.

\begin{abstract}
The presented article deals generally with the use of architecture to the propagation of the ideas and the use of structure of space for propagation of power influences of one group at the expense of another group. The use of architecture to the propagation of ideology lies in the tendency to shape ideologically acceptable space. Space is shaped so the world should be seen in accordance to the ideology and not to the reality. Architectural styles are specific for certain communities that are separated by land, culture, and time. Morphology is associated in architecture with a certain cultural epoch.

The article focuses on the use of architecture in propaganda of one totalitarian system - socialist realism, which is typical in the Czech cultural environment in 1948 - 1958. The architecture of socialist realism should promote sociability of people. The aim was to demonstrate the power of unity of collective and nothingness of human individuality.

A few examples of basic elements and characters in the architecture of real socialism in Ostrava are mentioned in the conclusion of the article.
\end{abstract}

\section{Introduction}

We live in space that forms us and our thinking and attitudes. We regard ourselves as freelyminded individuals considering the influence of space and the "talk" of shapes that regulate our "free" thinking every day insignificant. Architecture is often seen as a very narrow field, which is dealt with only by a small group of experts, but its relation to other fields of human endeavor is enormous, as it almost always takes place within it. Architecture works with the space, which is created by infinite number of combinations according to the conditions and requirements which can not be repeated and influence not only the final work, but also the perception and thinking of men moving in this area and becomes a space that influences social interaction by transformation of the material world. The manipulation of the readability of the space, in which we move and which we consider as natural precondition for life in the human community, was the most consistently practised in the architecture of the totalitarian regimes of the 20th century. [1]

Throughout the historical development there are milestones where a part of human society comes to the realization that their evolution just came to a dead end and it is inevitable to change something in order, that the development could continue. In the past, such significant changes were e.g. the migrations of peoples, which have been known since ancient times. If the individuals and nations want to survive, they have to find and create new conditions to overcome these changes. [2] The efforts of power groups have always been, and still are, to use these newly emerging conditions of life for enhancing the influence of the 'powerful' group on another group (of the controlled). They also try to create an environment favorable to the exercise of power. Urban and architectural models in non-totalitarian power systems of the society are derived primarily from the properties of the existing space (natural or artificially created). They draw inspiration from this space and they are based on the effect of this space. The architecture is not non-ideological even in non-totalitarian regimes, but the space must be, in totalitarian systems, entirely newly created under the pressure of ideology, covered with perfection and order of the corresponding to the only correct "new truth 
about the world." The immediately preceding development (e.g. the effort to exterminate the Jews, the prohibition of the religion and idealistic philosophical theories in communist states, forcible eviction of nations or their parts, elimination of the original settlements) is denied in order to change the historical context and establish a new ideology or a "new order " manifesting in creating an adequate space. $[2,3]$

Space and its readability is related to the coexistence conditions at all times of structured human community. The creation of populated space as a place for the exercise of state power becomes a goal in the rational modern society of the totalitarian regimes of the 20th century, Nazism and Communism [4]. In addition in the 20th century the realization of this effort was in addition supported by rapid technical and technological development, which unusually accelerated rate of formation of the "New World". The practice of communist totalitarian ideology implemented in the state management was (and has been), unlike the practice of the Nazi totalitarian ideology, limited in time (1933 -1945) and space (the territory controlled by Germany during the World War 2), much more widespread in time and space. Large residential residences covering considerable territories could be created on the basis of ideology, when pervasive propaganda became a tool to control, which does not allow a discussion or a rejection in contrast to persuasion. Any urban and architectural intervention in the environment entailed the ideological and propaganda meanings, which move the mind of the controlled men towards the "new worlds" which were being created. Planning as well as individual buildings have become a symbol and instrument of power. Monuments, squares, buildings of public facilities and residential buildings, as well as transportation construction or factory complexes had to confirm the individuals every day, that the new truth is already a reality [4]. It was (and still has been) not possible to avoid the view of them and therefore also their influence.

The architectural period of Sorela (the Czech term for the socialist realism derived from the first syllables of the words socialist realism and architect Zdeněk Lakomý's surname) is the architecture of the Central European area after 1948, which was the result of the communication of the state using buildings. The architecture should express a strong state power, its key function was political, moral and aesthetic education shaping revolutionary consciousness of man and it was completely subordinated to the vision of "higher whole." One of the most important realizations of Sorela are satellite towns around the center of Ostrava built on the basis of gigantic urban design of the new socialist cities of Havírov and of New Ostrava (Poruba), although neither of these projects have been implemented in the final design.

The following features can be considered the basic politico-ideological features of the architecture of the socialist realism:

- Consistent regularity of composition of urban plan which should have evoked the order

- Difficult understanding of the space

- Monumental form that refers to the smallness of the individual

- The use of historical elements to confirm the continuity of development

- Clearly ideological painting and statuary decoration

- Emphasis on ideological correctness of architecture at the expense of its quality [5].

Regularity of the Composition of the Urban Plan. It was based on the theoretical idea and vision of "ideal" cities of ancient times and Renaissance and designs of industrial-garden concepts of the city of the classicism, but with a strong emphasis on symmetry, regularity (regular systems of streets and closed residential blocks) towards monotony, which should eliminate the randomness and unpredictable variables. The traditional urbanism of blocks and squares with the dominant features in the axes and openings is implemented in maximal scale. 


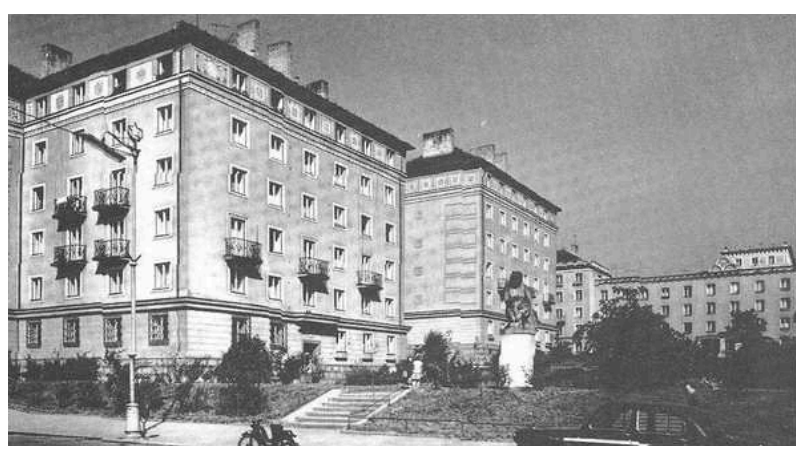

Fig. 1. Ostrava - Poruba [6]

Difficult Understanding of the Space. It was reflected in the lack of natural density of population of the settlements - anonymous places, large, regular and clearly arranged (controllable) free squares without intimate nooks practically eliminating friendly spontaneous meetings, except those which are intended to deliberately organized gathering to demonstrate loyalty to the power [3] (e.g. Main Street, former Lenin Street in Ostrava Poruba, Republic Square, former the Square of Victorious February in Havířov).

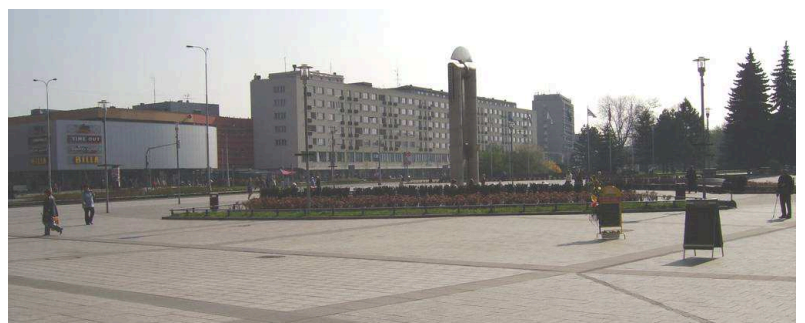

Fig. 2. Havířov - square and open space, the monument of V. I. Lenin was the dominant feature up to1990 [7]

The Monumental Form. It preferred to the economic aspect was based on admiration for height (the original inspiration by American skyscrapers) and the pursuit of monumentality and shocking monstrosity. The purpose of the monumental concept was to highlight the contrast between the insignificance of the individual and the power of the masses walking forward under the firm leadership of the power towards the utopia of communism. It should have confirmed the power of political establishment and strengthening the faith in the future. Arising structures copied monumental Soviet palaces. Many political monuments remained unfulfilled and many grand plans became their own caricatures for the lack of money and poor implementation.

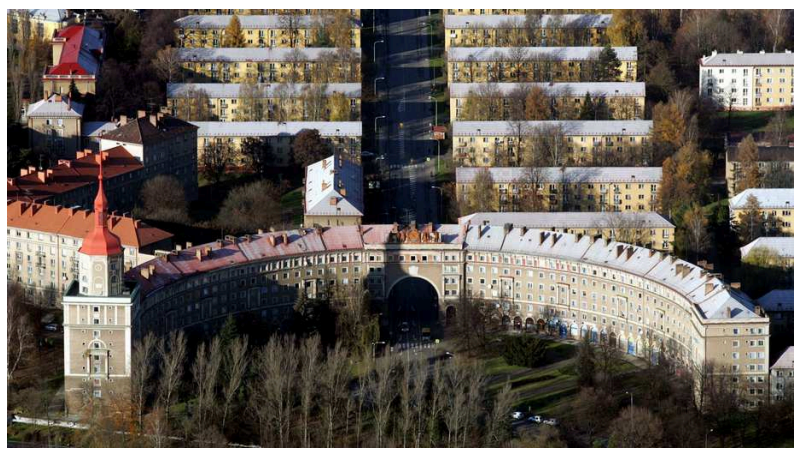

Fig. 3. Square U Oblouku, Ostrava - a copy of the headquarters of the Winter Palace in St. Petersburg, its ground plan has the shape of a sickle [8]

Historical Elements. Historical elements of parapet with axial gradation of stepped gables, gradation of the middle sections of objects, classicist style of colonnade, high pilaster orders, corner buttresses finished by spires, reliefs, bossages and friezes on facades were based on the ideas of the 
Renaissance and Classicism. The aim was to evoke a sense of continuity and inevitability of the anticipated development. Connection with some historical periods of architectural design and their incorporation into the current architecture was a prerequisite for the presentation of socialist realism as the only bridge to the future. Feudal Gothic or Catholic Baroque was unacceptable for ideological reasons, and on the contrary Classicism and Renaissance were acceptable.

Clearly Ideological Painting and Statuary Decoration. It was a combination of the constructive and patriotic themes (lime leaves) and is consistently applied in the decorative elements of the facades and the additional structures. The color scheme should have given the seeming of use of noble natural materials - natural stone with a light shade of sand and ocher color in combination with red terracotta and ecru off-white. Distinguishing characteristics of the stone, hardness, durability, constancy and almost infinite life-span, should have proclaimed the same characteristics as the ideology proclaimed.

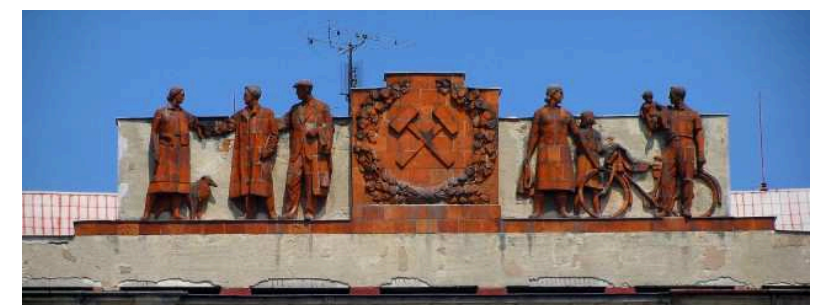

Fig. 4. Constructive motives of relief - Ostrava- Poruba [9]

The possibility to influence human thinking and behavior by transformation of the space is the force of architectural design and its natural artistic component. The architecture of the period of socialist realism can not be assessed without considering the historical context of its creation. And it is not possible to ignore the totalitarian patterns of its influence which were the purpose of its creation. Sorela was artificially implanted by brutal political force into the Czech milieu in the very limited time frame of a few years. Vast areas that have been effecting and will be effecting social relationships and perception of their inhabitants even over several generations, have been newly created in the ideology with unprecedented ideological mobilization of human and material resources.

\section{References}

[1] Z. Bauman, Globalizace - Důsledky pro člověka (Globalization - Implications for a Man), first ed., Mladá fronta, Praha, 1999.

[2] H. Arendt, Původ totalitarismu (Origin of the Totalitarianism), first ed., Oikoymeneh, Praha, 1996.

[3] J. Šamánek, Řeč architektury (The speech of Architecture), Architektura v perspektivě (2011) 30 -39 .

[4] P. Hušek, M. Wolfová, Propaganda v architektuře - totalitní režimy 20. století, Architektura v perspektivě (2011) $19-24$.

[5] Information on http://duoppa.ff.cuni.cz/

[6] Information on http://jarmik.pise.cz/111-sorela.html

[7] Information on http://www.geolocation.ws/v/W/File\%3AHavirov\%20sq01.JPG/-/en

[8] Information on http://cestovani.idnes.cz/ostravo-ostravo-panbuh-na-tobe-krasou-nesetril-f50/tipy-na-vylet.aspx?c=A061207_150843_igcechy_tom

[9] Information on http://commons.wikimedia.org/wiki/File:Ostrava-Poruba,_oblouk__podjezd,_2012_\%281\%29.JPG 